\title{
Ragam Kendangan Jogedan dalam Wayang Wong Golek Menak Gaya Yogyakarta Lakon Bedhahing Ambarkustub: Garap dalam Iringan Tari
}

\author{
Anon Suneko \\ Prodi Seni Karawitan ISI Yogyakarta
}

\begin{abstract}
This study aims to reveal a number of issues and problems regarding the variety of Yogyakarta-style wayang wong constraints given that its emergence has a background that relates to the existence of 16 types of characters in the puppet show that resemble the Yogyakarta style. The search was carried out through detailed observations of the intonation, articulation, accentuation and current in each type of fearful wayang golek in relation to identifying the character of the character and the choreography. Bedhahing Ambarkustub is one of the great examples of puppet stories used as a sample of this study. The method used in this research is qualitative method. The qualitative nature of this study is to explain the variety of jogedan beksa golek constraints that are Yogyakarta style through search based on authentic data while testing how far the jogedan ride is worked in supporting the presentation of dance performances, especially Yogyakarta style classical dance. Observation activities will reveal a systematic picture of the object chosen, namely the wayang wong, the play of Bedhahing Ambarkustub. These search results are expected to expand the study of karawitan science, especially music beksan or karawitan dance. The author hopes that through in-depth research on the design of the jogedan vehicle to be of the Yogyakarta style, the preservation and development of the great puppet show can take place more dynamically.
\end{abstract}

Keywords: kendangan; jogedan; menak; garap; accompaniment; dance

\begin{abstract}
Abstrak
Penelitian ini ini bertujuan untuk mengungkap beberapa hal dan permasalahan mengenai ragam kendangan jogedan wayang wong menak gaya Yogyakarta mengingat bahwa kemunculannya memiliki latar belakang yang berhubungan dengan adanya 16 tipe karakter dalam wayang golek menak gaya Yogyakarta. Penelusuran dilakukan melalui pengamatan yang detail terhadap intonasi, artikulasi, aksentuasi dan sekaran pada masingmasing jenis kendangan wayang golek menak dalam hubungannya identifikasi karakter tokoh beserta koreografinya. Bedhahing Ambarkustub merupakan salah satu pethilan cerita wayang golek menak yang digunakan sebagai sample penelitian ini. Metode yang digunakan dalam penelitian ini adalah metode kualitatif. Sifat kualitatif dalam penelitian ini adalah untuk memaparkan adanya ragam kendangan jogedan beksa golek menak gaya Yogyakarta melalui penelusuran yang berdasarkan data-data yang otentik sekaligus menguji seberapa jauh garap kendangan jogedan dalam mendukung presentasi pertunjukan seni tari khususnya tari klasik gaya Yogyakarta. Kegiatan observasi akan mengungkap gambaran sistematis terhadap objek yang dipilih yakni wayang wong menak lakon Bedhahing Ambarkustub. Hasil penelusuran ini diharapkan dapat memperluas kajian ilmu karawitan khususnya gending beksan atau karawitan tari. Penulis berharap bahwa melalui penelitian secara mendalam tentang pakem kendangan jogedan menak gaya Yogyakarta ini, maka kelestarian dan perkembangan iringan wayang golek menak dapat berlangsung lebih dinamis
\end{abstract}

Kata kunci: kendangan; jogedan; menak; garap; iringan; tari.

\section{Pengantar}

Wayang wong Menak yang seringkali disebut ringgit golek menak, wayang wong golek menak atau wayang golek menak merupakan salah satu wujud kekayaan karya seni istana Kasultanan Yogyakarta yang 
hingga saat ini terus hidup dan berkembang secara dinamis baik di dalam istana maupun luar tembok istana. Wayang wong Menak ini pada awalnya lahir atas gagasan Sri Sultan HB IX pada tahun 1941 setelah Beliau terkesan dengan sajian pertunjukan wayang golek yang dibawakan oleh Ki Dalang Widi Prayitno, seorang dalang wayang golek menak yang berasal dari Sentolo, Kulon Progo. Gagasan kreatif Sri Sultan HB IX untuk menciptakan wayang wong Menakini tampaknya bukan tanpa alasan. Sebagaimana para Sultan pendahulunya, Sri Sultan HB IX juga menginginkan suatu culture identity yang menjadi penanda masa pemerintahannya. Kalau penyempurnaan garap dan masa keemasan wayang wong terjadi pada era pemerintahan Sri Sultan HB VIII, maka identitas budaya yang menjadi penanda bagi Si Sultan HB IX adalah wayang wong menak atau wayang wong golek menak.

Pada tahun 1943 Sri Sultan HB IX merealisasikan gagasan penciptaan drama tari menak dengan didampingi pakar-pakar tari Keraton dengan 3 tipe karakter yang terwujud yakni putri, putra alus, dan gagah putra. Gairah pengembangan wayang wong menak muncul lagi pada tahun 1987. Tepatnya pada sarasehan yang kedua, tipe karakter pada wayang wong menak telah berkembang menjadi 16 tipe karakter.

Stilisasi gerak wayang golek yang patah-patah menjadi abstraksi gerak yang menarik, sejalan dengan ide dasar Sri Sultan Hamengku Buwono IX untuk meramu gerakan tersebut menjadi lebih alami berdasarkan unsur silat Sumatra Barat (silat Tuo dari Maninjau - untuk peranan halus dan putri) juga kemungkinan sikap-sikap Kung Fu dalam adegan "Perang" yang disentuh dengan kendang Sunda dan perlu juga pengkajian terhadap sikap-sikap peperangan zaman itu (misalnya Zaman Jengiskhan) dan sebagainya.

Perangkat gamelan yang mengiringi pertunjukan beksa golek menak secara garis besar sama dengan gamelan untuk mengiringi wayang wong gaya Yogyakarta, yang terdiri dari perangkat lengkap yang berlaras slendro dan pelog. Walaupun gending-gending yang digunakan sebagai iringan agak mirip dengan gending-gending pada pertunjukan wayang wong purwa, tetapi ada beberapa gending yang khas untuk beksa golek menak yang agak bernuansa pedesaan, misalnya Kembang Jeruk, Redi Guntur, dan sebagainya. Yang lebih khas dari iringan beksa golek menak adalah permainan kendangnya yang lebih banyak menggunakan kendangan batangan atau ciblon, yang menyesuaikan dengan gerak-gerak tari beksa golek menak yang banyak menggunakan bunga-bungaan gerak.

Enam belas tipe karakter dalam wayang golek menak memiliki ciri khas kendangan yang dapat dibedakan melalui pengamatan yang detail terhadap intonasi, artikulasi, aksentuasi dan sekaran pada masing-masing jenis kendangan wayang golek menak. Penelusuran lebih jauh tentang kendangan jogedan wayang golek menak Gaya Yogyakarta dapat dilakukan melalui identifikasi kendangan jogedan pada 16 tipe karakter pada wayang wong menak sehingga persamaan dan perbedaan spesifikasi kendangan jogedan dapat dideskripsikan secara jelas.

Berdasarkan pemaparan di atas, ragam kendangan jogedan wayang wong menak dalam karawitan iringan tari Gaya Yogyakarta sangat penting untuk diteliti mengingat kemunculannya memiliki latar belakang yang dipengaruhi oleh faktor eksternal yang dalam hal ini adalah seni tari sebagai partner presentasi estetik seni karawitan. Garap sajian wayang wong menak gaya Yogyakarta telah mengalami perubahan dari masa ke masa. Beberapa dokumen video pementasan wayang wong menak pada tahun 90-an dalam beberapa lakon antara lain: Kelaswara Palakrama, Jayengrana Winiwaha, Sayembara 
Hisnaningsing memberikan petunjuk terhadap penulis dalam merunut perkembangan garap kendangan jogedan dalam wayang wong menak gaya Yogyakarta. Oleh karena adanya beberapa referensi garap kendangan jogedan pada banyak lakon atau judul wayang wong menak yang pernah dipentaskan dan terdokumentasi maka penulis akan mengambil salah satu lakon sebagai sample dalam melakukan penelitian garap kendangan jogedan. Pembatasan pada sample salah satu lakon bertujuan untuk memfokuskan penelitian sehingga dengan kajian yang mendalam pada satu fokus objek lakon yakni Bedhahing Ambarkustub yang diproduksi oleh Yayasan Pamulangan Sasminta Mardawa (YPBSM) telah digelar dalam Festival Wayang Wong Menak gaya Yogyakarta yang diselenggarakan oleh Dinas Kebudayaan Provinsi Daerah Istimewa Yogyakarta pada tanggal 6 sampai 8 Mei 2018 di Pendopo Akademi Komunitas Seni Budaya Yogyakarta.

Penelitian ini akan menjawab beberapa permasalahan dalam identifikasi tipe karakter dan garap kendangan jogedan dalam sajian wayang wong menak gaya Yogyakarta lakon Bedhahing Ambarkustub. Penulis berharap bahwa melalui penelitian secara mendalam tentang kendangan jogedan menak gaya Yogyakarta ini, maka kelestarian dan perkembangan iringan wayang golek menak khususnya kendangan jogedan dapat berlangsung lebih dinamis karena pakem kendangan jogedan wayang golek menak sebagai dasar pijakan dapat dipahami secara utuh.

Untuk mengetahui sejauh mana ragam kendangan jogedan beksa golek menak dalam menopang kebutuhan tari, sangat tepat apabila digunakan pendekatan koreografis. Selain itu selalu diadakan pengamatan secara langsung di lapangan yang kadang kala menjadi insider sebagai metode empiric yang ditransformasikan menjadi bahasa tulisan. Mengingat bahwa hal-hal tersebut merupakan produk seni yang dalam presentasinya menuntut nilai keindahan, maka digunakan pula pendekatan estetika.

Metode empirik digunakan dalam menganalisis atas dasar pengalaman yang dialami oleh pelaku seni pada waktu menemui berbagai masalah maupun mengalami pengalaman estetiknya. Motode tersebut diterapkan dalam penelitian ini karena pengalaman yang dimiliki dalam praktik lapangan perlu ditransformasikan ke dalam bentuk tulisan.

Metode yang digunakan dalam penelitian ini adalah metode kualitatif. Sifat kualitatif dalam penelitian ini adalah untuk memaparkan adanya ragam kendangan jogedan beksa golek menak gaya Yogyakarta melalui penelusuran berdasarkan data-data yang otentik sekaligus menguji seberapa jauh garap kendangan jogedan dalam mendukung presentasi pertunjukan seni tari khususnya tari klasik gaya Yogyakarta. Kegiatan observasi akan mengungkap gambaran sistematis tentang peristiwa kesenian, tingkah laku (kreasi dan apresiasi), dan berbagai perangkat (medium dan teknik) pada tempat penelitian (studio, galeri, ruang pamer, komunitas, dsb.) yang dipilih untuk diteliti dengan memperhatikan karya seni, ruang dan tempat, pelaku, kegiatan, waktu, peristiwa, tujuan, dan perasaan.

Pengumpulan data dilakukan melalui studi pustaka dan wawancara kepada narasumber di antaranya: pertama, K.R.T. Purwaningrat, salah satu pengendang di Keraton Yogyakarta yang dianggap memiliki pengalaman secara langsung dalam selukbeluk perkembangan karawitan gaya Yogyakarta pada masa pemerintahan Sri Sultan HB IX dan Sri Sultan HB X; kedua, K.M.T. Purwodipuro, seorang akademisi ISI Yogyakarta, abdi dalem Pura Pakualaman Yogyakarta yang dalam profesinya di 
lapangan sebagai pengendang dianggap berkompeten dalam memberikan keterangan-keterangan kaitannya dengan garap kendangan tari tradisi Yogyakarta; ketiga, Drs. Supriyadi, M.Sn, praktisi sekaligus akademisi Jruusan Tari, ISI Surakarta yang diharapkan dapat memberikan data-data berdasarkan pengalamannya selama berkecimpung secara langsung dalam dunia seni tari klasik gaya Yogyakarta.

Identifikasi Keragaman Kendang Ladrang dalam Iringan Tari Gaya Yogyakarta

Identifikasi karakter dan garap kendangan jogedan dalam wayang wong menak gaya Yogyakarta dalam lakon Bedhahing Ambarkustub.

Dunia tari sebagai salah satu partner karawitan dalam proses interaksi yang intim telah mempengaruhi perkembangan karawitan melalui proses sinkronisasi beberapa elemen yang berorientasi pada pemenuhan kebutuhan tari. Beberapa perubahan, pengembangan, maupun penyesuaian sebagai hasil penafsiran dari tradisi wayang golek menak yang sudah ada dilakukan demi memenuhi kebutuhan estetika sajiannya.

Kendangan jogedan yang dibawakan dengan kendang batangan merupakan salah satu ciri yang membedakan wayang golek menak dengan wayang wong gaya Yogyakarta. Sepeti halnya wayang topeng yang banyak berkembang di luar tembok istana, ragam gerak tari yang ada didalamnya dihidupkan melalui permainan sekaran kendang yang spesifik dengan menggunakan kendang ciblon atau batangan yang mendukung presentasi estetis disetiap sajian pertunjukannya. Sekaran kendang jogedan mengalami proses pengembangan dan modifikasi yang secara fisik tampak pada aksentuasi, filler, intonasi, intensitas sehingga terbentuklah karakter kendangan yang berbeda pada masing-masing karakter peran. Pembawaan kendangan jogedan inilah yang dapat menjadikan gerak tari atau karakter tokoh yang sedang diperankan menjadi semakin hidup dan lebih dinamis. Menurut Romo Suyamto, munculnya garap khusus dalam struktur gending beksan dipengaruhi oleh kebutuhan penguatan aksentuasi gerak dalam koreografi, karakter dan suasana. Munculnya beberapa sekaran kendangan jogedan pada wayang golek menak merupakan salah satu contoh bahwa didalam orientasi karawitan sebagai iringan tari sering kali terjadi pengembangan dari pakem yang telah berlaku karena tuntutan pengembangan ragam gerak dalam koreografinya. Hal ini secara positif menambah alternatif garap kendangan yang akan memperkaya warna sekaran kendangan jogedan dalam peta perkembangan wayang wong golek menak di Yogyakarta.

Dalam suatu kesempatan wawancara dengan Supriyanto selaku sutradara dalam pementasan wayang golek menak lakon Bedhahing Ambarkustub, penulis memperoleh paparan mengenai interpretasi karakter dan suasana pada setiap adegan yang menjadi acuan dalam olah garap iringan tari wayang golek menak tersebut. Lakon Bedhahing Ambarkustub versi YPBSM merupakan adaptasi dari paparan cerita golek menak versi Ki Narto, seorang dalang wayang golek menak asal dari Kebumen, Jawa Tengah, selaku 
narasumber dalam produksi lakon tersebut. Penata iringan mengacu pada naskah yang diadaptasikan kembali oleh Supriyanto atas dasar pertimbangan pemenuhan kebutuhan dinamika adegan menurut interpretasi kolektif tim kreatif YPBS. Setiap adegan yang tertulis dalam naskah telah dilengkapi dengan urutan adegan, gambaran suasana adegan, sasmita gending yang mendukung suasana, dialog serta keterangan lampah secara detail. Sehingga dalam proses produksi wayang golek menak ini, penata iringan harus titis dalam menafsirkan sasmita, suasana adegan dan karakter gendingnya. Berikut ini adalah deskripsi naskah yang mengilustrasikan adegan pertama dalam wayang golek menak lakon Bedhahing Ambarkustub atau Bedhah Negari Ambarkustub produksi YPBSM dalam Festival Wayang Wong Menak pada tahun 2018:

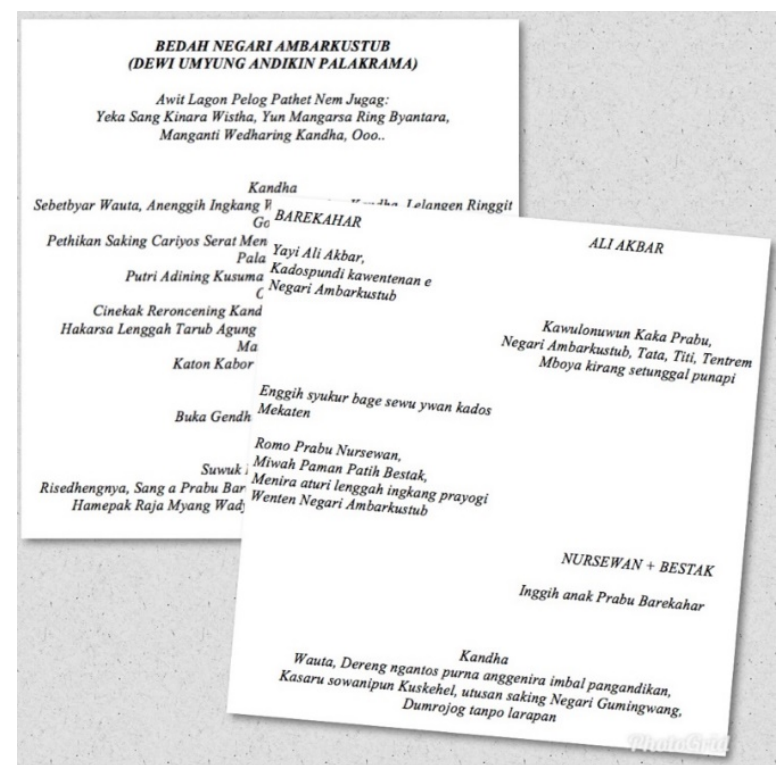

Gambar 1. Deskripsi Naskah wayang golek menak lampahan "Bedhahing Ambarkustub" pada adegan I

(Foto: Anon Suneko)
Deskripsi naskah adegan pertama diatas menginformasikan beberapa hal yang dijadikan petunjuk pada penggarap baik sutradara, tari, kostum, artistik maupun iringan dalam menafsirkan serta merealisasikannya dalam presentasi yang nyata. Beberapa hal yang spesifik dalam adegan pertama dituturkan oleh pamaos kandha seperti Cinekak Reroncening Kandha, Kocap a Prabu Barekahar, Hakarsa Lenggah Tarub Agung Wewangunan, Yen Sinawang Saking Mandrawa,Katon Kabor Gebyaring Busana. Selain menyampaikan point atau intisari adegan beserta tokoh utama yang menjadi center dalam adegan ini, kandha juga diakhiri dengan sasmita gendhing seperti layaknya wayang purwa yang mengindikasikan judul suatu gending pengiring pada jejeran pertama ini.

Adapun tokoh-tokoh yang terlibat dalam presentasi di adegan pertama ini adalah sebagai berikut: Barekahar, Ali Akbar, Kuskehel, Bestak, Nursewan, Umyung Andikin serta 3 punggawa kerajaan Ambarkustub. Barekahar, Ali Akbar, Kuskehel, Bestak, Nursewan beserta 3 orang punggawa diinterpretasikan dalam karakter joged menak putra gagah, sedangkan Umyung Andikin dibawakan dengan karakter joged menak putri alus. Jelaslah disini bahwa ditinjau secara global dalam satu adegan akan terdapat lebih dari satu karakter. Secara detail lagi, karakter karakter gagah akan dimanifestasikan dalam koreogafi yang beragam sesuai pakem jogedan pada masing-masing jogedan jogedan yang sudah disepakati dalam beksa golek menak gaya Yogyakarta. Dengan demikian maka 
garap kendangan jogedan akan menjadikan indentifikasi karakter diatas sebagai acuan tafsir atau interpretasi sekaran kendangan jogedan utuk mendukung presentasi gerak tariannya. Berikut ini adalah hasil identifikasi karakter pada adaegan utama yang meliputi jejeran Ambarkustub, Pertapan Wukir Kumbara, dan Koparman.

\begin{tabular}{|c|c|c|}
\hline Adegan & Tokoh & Karakter \\
\hline $\begin{array}{l}\text { Jejer } \\
\text { Ambarkustub }\end{array}$ & $\begin{array}{l}\text { Barekahar } \\
\text { Ali Akbar } \\
\text { Kuskehel } \\
\text { Bestak } \\
\text { Nursewan } \\
\text { Umyung } \\
\text { Andikin } \\
\text { Marmadi } \\
\text { Tamtanus }\end{array}$ & $\begin{array}{l}\text { Putra Gagah } \\
\text { Putra Gagah } \\
\text { Putra Gagah } \\
\text { Putra Gagah } \\
\text { Putra Gagah } \\
\text { Putri Halus } \\
\text { Putra Gagah } \\
\text { Putra Gagah }\end{array}$ \\
\hline $\begin{array}{l}\text { Jejer Wukir } \\
\text { Kumbara }\end{array}$ & $\begin{array}{l}\text { Datuk } \\
\text { Barganis } \\
\text { Putri Siswa } \\
\end{array}$ & $\begin{array}{l}\text { Putra Gagah } \\
\text { Putri } \\
\text { mbranyak }\end{array}$ \\
\hline $\begin{array}{l}\text { Jejer } \\
\text { Koparman }\end{array}$ & $\begin{array}{l}\text { Jayengrana } \\
\text { Haryo Maktal } \\
\text { Umarmaya } \\
\text { Semakun } \\
\text { Lamdahur }\end{array}$ & $\begin{array}{l}\text { Putra Halus } \\
\text { Putra Gagah } \\
\text { Putra Gagah } \\
\text { Putra Gagah } \\
\text { Putra Gagah }\end{array}$ \\
\hline $\begin{array}{l}\text { Setel } \\
\text { ggedan }\end{array}$ & $\begin{array}{l}\text { karakter } \\
\text { secara }\end{array}$ & $\begin{array}{c}\text { dan raga } \\
\text { koreograf }\end{array}$ \\
\hline
\end{tabular}

teridentifikasi, maka seorang pemain kendang akan menginterpretasikan hasil identifikasi jogedan dan dimanifestasikan dalam sekarang kendang jogedan menak berdasarkan konvensi tradisi iringan beksa golek menak gaya Yogyakarta yang telah disepakati oleh para pakar-pakar tari istana Kasultanan Ngayogyakarta atas inisiatif Sri Sultan HB IX.

Berdasarkan hasil pengamatan secara langsung maupun tidak langsung, maka sampai dengan tahap penelitian ini penulis telah dapat mengetahui bahwa dalam garap iringan tari wayang golek menak lakon Bedhahing Ambarkustub terdapat beberapa karakter peran yang terdapat dalam satu adegan. Dalam konvensi tradisi wayang golek menak, beberapa karakter atau tokoh ini kemudian diidentifikasi agar garap kendangan jogedan dapat memenuhi prioritas suasana atau karakter yang ada pada setiap adegan. Dengan demikian, diantara beberapa ragam jogedan, kendang hanya akan responsif menguatkan salah satu karakter peran yang disepakati menjadi karakter dominan untuk menghidupkan adegan menjadikannya lebih dinamis.

Berdasarkan naskah wayang golek menak lakon Bedhahing Ambarkustub, maka beberapa gending yang dipakai untuk mengiringi sajian wayang golek menak lakon Bedhahing Ambarkustub secara urut adalah sebagai berikut:

a. Ladrang Kabor, Slendro Nem untuk mengiringi adegan Jejer Ambarkustub. Gending ini mengiringi jogedan Barekahar $\neg$ dan punggawa dalam karakter gagah. Gending dibawakan dalam irama I dengan kendang kalih dan irama II dengan garap kendangan batangan mengikuti aksentuasi ragam jogedan menak.

b. Ladrang Wirangrong, Pelog Bem untuk mengiringi adegan Pertapan Wukirkumbara. Gending ini mengiringi jogedan Barekahar $\urcorner$ dan punggawa dalam karakter gagah. Gending dibawakan dalam irama I dengan kendang kalih dan irama II dengan garap kendangan batangan mengikuti aksentuasi ragam jogedan menak.

c. Ladrang Kenceng, Slendro Manyura, untuk mengiringi adegan Jejer Koparman yakni Jayengrana serta para punggawa. Gending dalam 
adegan ini berkarakter gagah serta berwibawa.

d. Ganjur, Pelog Barang, untuk mengiringi adegan Perang Brubuh

e. Ketawang Sitamardawa, untuk mengiringi adegan perang Umyung Andikin dengan Kadarwati. Ketawang ini disajikan dalam garap lirihanᄀ, irama II dengan garap kendangan batangan yang mengacu pada asentuasi gerakan tari.

f. Gati Wiwaha, Pelog Barang untuk mengiringi adegan Panggih sekaligus sebagai adegan penutup. Dalam gending ini, seluruh tokoh membawakan ragam jogedan masingmasing, sedangkan kendang tetap mengacu pada jogedan menak gagah.

Pembahasan

Garap Kendhangan Jogedan dalam Wayang Wong Golek Menak lakon Bedhahing Ambarkustub

Garap karawitan tari adalah sebuah kerja pertunjukan seni karawitan yang mengimplementasikan kaidahkaidah dalam ilmu karawitan, untuk membantu membentuk atmosfir dalam sebuah pertunjukan tari. Kendhangan sebagai salah satu unsur penting dalam karawitan tari juga mengimplementasikan pola-pola baku dalam dunia karawitan kedalam iringan beksan.

Sesuai dengan sasmitaning gendhing yang terdapat dalam kandha, maka gending yang digunakan sebagai pengiring adegan pertama adalah Gendhing Kabor laras Slendro pathet Nem kendhangan Ladrang. Adapaun skema kendangan jogedan jika digambarkan dalam struktur gending dengan ricikan kolotomik atau struktural yang menjadi acuan bagi tari adalah sebagai berikut:

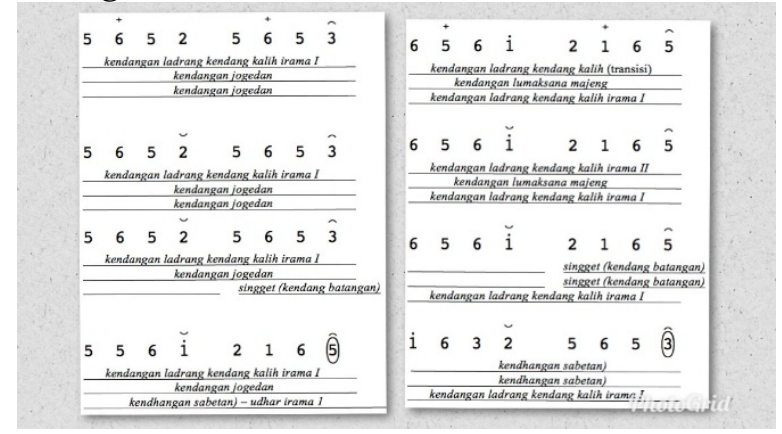

Gambar 2. Skema kendangan wayang golek menak pada jogedan adegan I

(Foto: Anon Suneko)

Kendangan Jogedan pada Jejer Negari Ambarkustub

Sabetan :

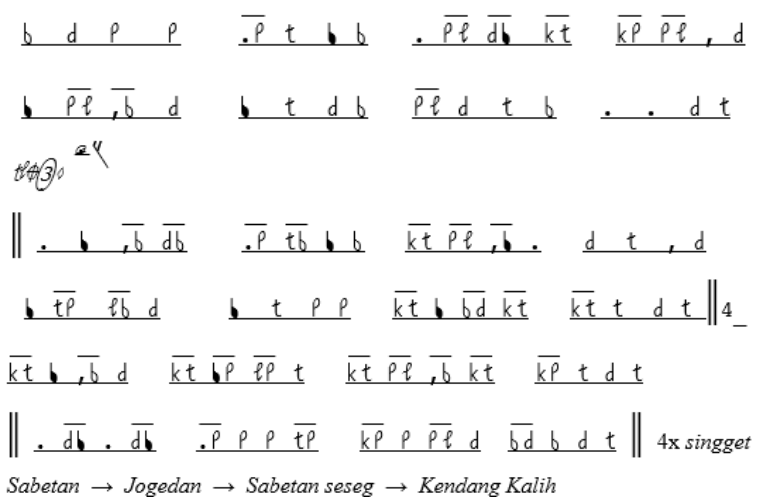

Kendangan Jogedan Bidhalan

Singget :

.. $\bar{\rho} \overline{l p} \mathrm{t} \rho \overline{\rho \ell}, f d b \quad . d t$

Sabetan $\rightarrow$ Jogedan $3 x \rightarrow$ Sabetan (udar wirama I)

Muryani Busana (Irama I)

$d b b, \quad \rho \overline{\rho_{l}}, \bar{p} t \overline{t b} \ell b, d t, \overline{t p}$

$\overline{p l} \overline{t P} \overline{l p} \overline{t P} \quad \overline{l p} t b \quad d \quad \overline{p l} d \quad t \quad b \quad \bar{p} \overline{p l}, \bar{p} t$

$d t \overline{\rho_{l}} d \overline{\rho_{l}} d d t \quad \overline{k t} \overline{\rho_{l}}, \bar{b} . \underline{d}, \underline{d}$

$b \overline{t p} \overline{l b} d t P p \overline{k t} b \overline{b d} \overline{k t} \overline{k t} t d t$

$d p b \cdot \quad p \overline{p l} \cdot \bar{p} t \overline{t b} \ell b, d t, \overline{t p}$

$\overline{l p} \overline{t P} \overline{\ell p} \overline{t p} \overline{l p} t_{b} \quad d \quad \overline{p l} d \quad t \quad b \quad . \quad . \overline{. d} t$

Lumaksana :

$\|\cdot \overline{d b} \cdot \overline{d b} \overline{\cdot p} \rho \rho \overline{t p} \overline{k p} \rho \overline{\rho l} d \overline{b d} b d t\| 6 x$ Trisik :

$\overline{. b} \overline{p_{l}} \overline{b d} b \quad \overline{b d} \overline{b \cdot \bar{t}} \overline{. t} t . \overline{p_{l}} \overline{b b} \overline{k t} \overline{k p} \overline{p_{l}}, d$

$b \overline{p_{l}, \bar{b} d} b t d b \overline{p_{l}} t \quad \ldots d t$ 
Muryani Busana:

$\| d p b . \quad p \overline{p l}, \bar{p} t \overline{t b} l b, d t, \overline{t p}$ $\overline{l p} \overline{l \rho} \overline{l p} \overline{l \rho} \overline{l p}+b \quad d \overline{. p} \overline{p l}, \bar{p} t \|_{2 x}$

Mipil:

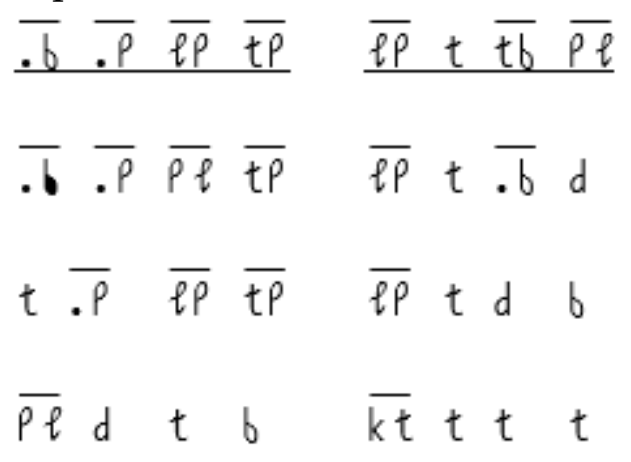

Nyamber :

. $\overline{b d} \cdot \cdot \overline{b d} \overline{b \cdot t} \cdot \bar{t} t$

$\overline{b d} \overline{b \cdot t} \overline{\cdot t} t \overline{b d} \overline{b \cdot t} \overline{\cdot t} t$

Ater-ater Mlebet Playon:

b $t$ b $t \quad P$ P P P d d P b . t t t

Pemain kendang dalam sajian wayang wong golek menak lakon Bedhahing Ambarkustub, secara atraktif merespon karakter joged gagah, putri, dan gagah gecul dengan berdasarkan acuan tradisi dan referensi beberapa pengembangan sekaran kendang jogedan menak. Dalam gerak tayungan atau lumaksana, kendang akan selalu merespon karakter pembawaan ragam joged putri, atau karakter geculan (jika ada). Pada beberapa adegan yang menampilkan beraneka macam karakter, maka kendangan akan mengacu pada ragam gerak gagah dan sebaliknya, ragam gerak putra halus maupun putri akan mengikuti aspek wirama dari kendangan jogedan.

Berikut ini adalah transkrip salah satu sekaran kendang jogedan yang secara atraktif menguatkan aksentuasi, ritme, dan jiwa ragam gerak tarinya.
Kendangan Joged dan lumaksana pada Jejer Pertapan Wukir Kumbara

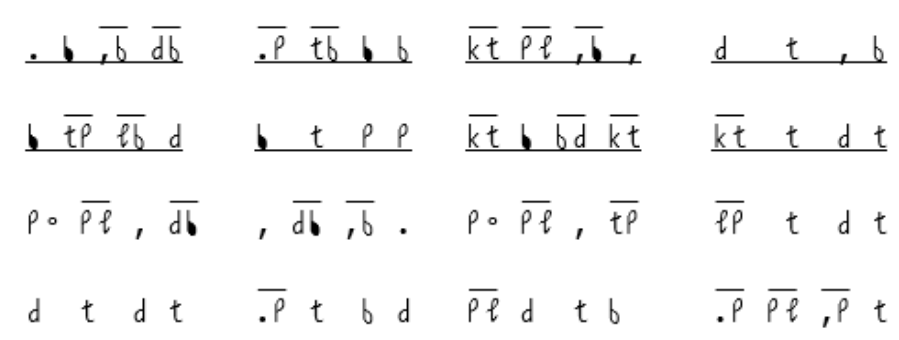

Lumaksana :

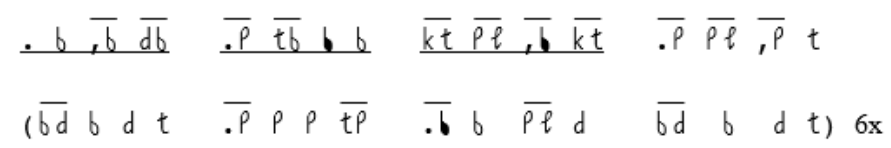
Jogedan Umarmaya:

. $b, \bar{b} \overline{d b} \quad \bar{p} \overline{t b} b b \quad \overline{k t} \overline{p l}, \bar{b}$. d $t, d$

b $\overline{t \rho} \overline{l b} d \quad b \quad t \quad P \rho \overline{k t} b \overline{b d} \overline{k t} \overline{k p} t d t$

$, \overline{t \rho} \overline{\rho l} \overline{t \rho} \overline{l \rho} \mathrm{t} d \mathrm{t} \overline{\mathrm{kt}} \overline{\rho l} \overline{, \sigma} \overline{k t} \overline{, \rho} \overline{\rho l}, d$

$b, \overline{. b} d \quad b t$ te $l \overline{k t} b \overline{b d} \overline{k t} \overline{k P} t d t$

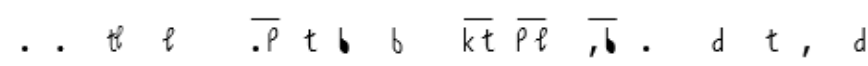

$b \overline{t p} \overline{l b} d \quad b t \quad p \quad p \quad \overline{k t} b \overline{b d} \overline{k t} \overline{k p} t d t$

. $t \overline{\rho l} d \overline{\rho l} d d t \overline{k t} \overline{\rho l} \overline{. b} \overline{k t} \overline{. p} \overline{\rho l}, d$

$b, \overline{. b} d \quad b t$ th $\ell \overline{k t} b \overline{b d} \overline{k t} \overline{k P} t d t$

- b $\overline{, b} \overline{d b} \quad \overline{. p} \overline{t b}$ b b $\overline{k t} \overline{p l} \overline{, b} . d t, b$

Dari pengamatan penulis di lapangan baik secara langsung maupun melalui dokumen audio visual, pembawaan sekaran kendhangan jogedan menak ini menerapkan fleksibilitas permainan kendang yang secara tradisi telah terindentifikasi dalam dua peran yakni mirama dan miraga. Mirama adalah ketika kendang hanya berperan sebagai indikator ritme, sehingga kadangkadang kurang memberikan kontribusi terhadap karakteristik sebuah tarian dan kadang-kadang bersifat ilustratif karena memang hanya menitik beratkan aspek ritme dalam musikalitas gending beksan. 
Miraga adalah ketika kendang dapat memberikan motivasi gerak untuk berekspresi, atau dapat dikatakan "matut solahing beksa". Fleksibilitas kendang dalam dua peran ini benar-benar diperhatikan secara cermat oleh pengendang sehingga keseimbangan estetika gending beksan dapat dinikmati secara sempurna dari sisi musikalitas maupun kesatuannya dengan tari yang diiringi.

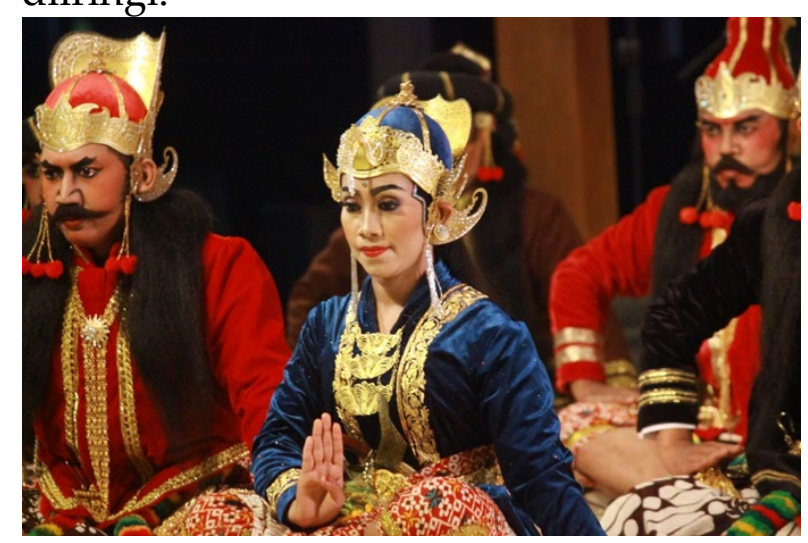

Gambar 2. Salah satu adegan dalam jejer Ambarkustub

(Foto : Seta Wikandaru, 2018)

\section{Penutup}

Dalam sajian Wayang Wong Golek Menak lakon Bedhahing Ambarkustub terdapat 3 jejeran dan 3 adegan lain yang mempresentasikan beberapa ragam jogedan. Karakter, suasana dan identifikasi tokohtokoh yang tampil pada setiap adegan menjadi dasar tafsir garap kendangan jogedan didalamnya. Permainan kendangan jogedan secara responsif menghidupkan suasana dengan dasar prioritas pada karakter atau tokoh yang diutamakan dalam setiap adegan menurut tata aturan garap wayang wong Gaya Yogyakarta pada umumnya.

Aplikasi kendhangan jogedan menak lakon Bedhahing Ambarkustub muncul pada bentuk gending ladrang, ketawang, dan ganjur. Sekaran kendangan jogedan dalam garap iringan wayang golek menak Gaya Yogyakarta merupakan manifestasi pemenuhan akan kebutuhan penguatan aksentuasi gerak dan penguatan karakter suatu karakter ragam gerak dalam tari yang diiringi. Ketika koreografi dari ragam jogedan berkembang kian dinamis dari masa ke masa, maka garap kendangan jogedan wayang wong golek menak juga akan mengalami perkembangan pula dari masa ke masa. Hubungan intim antara karawitan dan tari yang telah lama terjalin saling menginspirasi dan semakin memperkaya khasanah garap kendang gending beksan Gaya Yogyakarta.

Berkembangnya banyak lakon wayang wong golek menak serta beberapa versi garap sajian di Yogyakarta merupakan potensi yang perlu diteliti secara lebih lanjut untuk mendukung akurasi temuan-temuan yang sudah dicapai dalam penelitian ini. Pengembangan interpretasi aspek koreografi terhadap tokoh-tokoh yang masih jarang ditampilkan memberikan ruang bagi para pengendang untuk mengimplementasikan penguatan gerak jogedan menak melalui sekaran kendangan beragam yang akan memperkaya referensi garap gending beksan

\section{Referensi}

Djelantik, A.A.M. (2001), Estetika Sebuah Pengantar, Masyarakat Seni Pertunjukan Indonesia, Bandung.

Hastanto, Sri. (1997), “Pendidikan Karawitan

Situasi Problema dan Anganangan", dalam Wiled: Jurnal Kesenian STSI Surakarta, Surakarta. Lindsay, Jennifer. (1979), Javanese Gamelan, Oxford University Press, Malaysia. Pudjasworo, Bambang. (2018), “Tari Golek Menak dalam Dialektika Perkembangan Tari Gaya Yogyakarta", Makalah pada Sarasehan Budaya di Dinas Kebudayaan Provinsi DI Yogyakarta. 
Martopangrawit. (1975), Pengetahuan Karawitan 2, ASKI Surakarta, Surakarta. Petunjuk Praktek bagi Guru), Terj. Ben Suharto, Ikalasti, Yogyakarta.

Sri Murywati Darmokusumo. (1989), Tari Golek Menak, Anjungan D.I.Yogyakarta didukung oleh Yayasan Guntur Madu.

Smith, Jacqueline. (1976). Dance Composition: A practical Guide For Teacher, (Komposisi Tari: Sebuah

R.M. Soedarsono \& Tati Narawati. (2011), Dramatari di Indonesia, Kontinuitas dan Perubahan, Yogyakarta.

Soeroso. (1989), "Pengetahuan Karawitan", Proyek Peningkatan dan Pengembangan ISI Yogyakarta, DEPDIKBUD.

Suharti, Theresia. (2015), Bedhaya Semang Kraton Ngayogyakarta Hadiningrat Reaktualisasi sebuah Tari Pusaka, PT Kanisius, Yogyakarta.

Supanggah, Rahayu. (2002), Bothekan Karawitan I, Ford Foundation dan Masyarakat Seni Pertunjukan Indonesia, Jakarta.

(2009), Bothekan Karawitan II, Program Pascasarjana bekerja sama dengan ISI Press Surakarta, Surakarta.

Tim Penyusun. (1988), Kamus Besar Bahasa Indonesia, Balai Pustaka, Jakarta. 